\title{
Calcifying supracoracoid bursitis as a cause of chronic shoulder pain
}

\author{
J. MENS AND J.K. VAN DER KORST \\ From the Jan van Breemen Institute, Centre for Rheumatology and Rehabilitation, Amsterdam, \\ The Netherlands
}

SUMMARY A case of chronic shoulder pain is reported with marked limitation of both active and passive elevations and a normal range of motion of the glenohumeral joint. $X$-ray examination demonstrated cloudy calcification in the coracoclavicular region, presumably indicating calcifying supracoracoid bursitis.

We report the clinical and radiological findings in a patient with calcifying supracoracoid bursitis.

\section{Case report}

A 71-year-old woman reported with shoulder pain of about five years' duration, which had developed gradually. On physical examination there was painful limitation of left shoulder movements, especially total elevation, both in abduction and in flexion. $X$-rays showed cloudy calcification between the

Accepted for publication 13 January 1984.

Correspondence to J. Mens, MD, Jan van Breemen Institut, Jan van Brecmenstraat/Adm. Helfrichstraat, $1056 \mathrm{AB}$, Amsterdam. The Netherlands. coracoid process and the conoid tubercle of the clavicle (Fig. 1). The calcification was also visible on chest $x$-rays taken in 1976 and 1978, but not in 1972 . The area between the coracoid process and the clavicle was found to be extremely tender on palpation. The area was infiltrated-2.5 to $3.5 \mathrm{~cm}$ deep-with $5 \mathrm{ml}$ lignocaine hydrochloride $2 \%$. No fluid could be aspirated, but the calcification was clearly felt to touch the tip of the needle. Immediately after the injection the shoulder function improved markedly (Table 1 ). Six weeks later the patient was completely free of pain, and the normal range of motion had been restored, though $x$-ray examination showed the calcifications to be completely unaltered.

Table 1 Mobility of the shoulders in a patient suffering from chronic supracoracoid bursitis (left-sided) before and after local analgesic injection

\begin{tabular}{lccc}
\hline Shoulder & Right & $\begin{array}{l}\text { Left before } \\
\text { injection }\end{array}$ & $\begin{array}{c}\text { Left after } \\
\text { injection }\end{array}$ \\
\hline $\begin{array}{l}\text { Total active abduction- } \\
\text { clevation }\end{array}$ & 180 & $80 \dagger-110 \S$ & $175 \dagger$ \\
$\begin{array}{l}\text { Total passive abduction- } \\
\text { clevation }\end{array}$ & 180 & $80 \dagger-110 \S$ & $175 \dagger$ \\
$\begin{array}{l}\text { Passive abduction with } \\
\text { fixcd scapula }\end{array}$ & 100 & 100 & 100 \\
$\begin{array}{l}\text { Passive external rotation } \\
\begin{array}{l}\text { Passive internal rotation } \\
\text { Passive horizontal }\end{array}\end{array}$ & 70 & $70 \ddagger$ & $70 \dagger$ \\
hyperadduction & 100 & $90 \ddagger$ & $90 \dagger$ \\
\hline
\end{tabular}

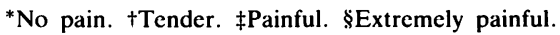




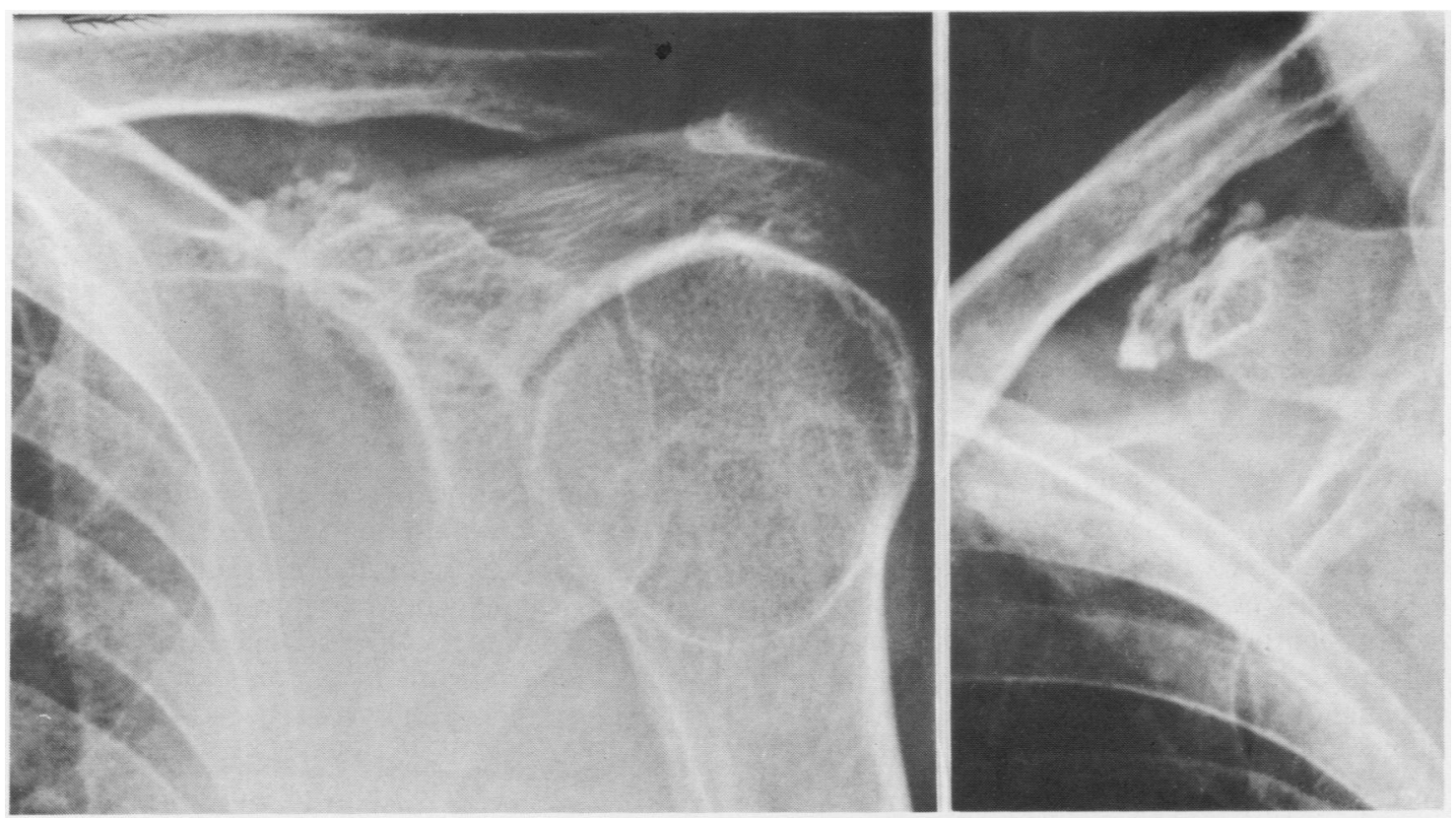

Fig. 1 X-ray photographs in chronic supracoracoid bursitis. Left: Cloudy calcification in the coracoclavicular region while the arm is in zero position and the direction of the $x$-rays is horizontal. Right: Arm is in $90^{\circ}$ anteflexion and the $x$-rays are from anterocaudal to posterocranial.

\section{Discussion}

The coracoid process and the clavicle are connected by two coracoclavicular ligaments. These arise from the 'elbow' and part of the upper process of the coracoid process and are inserted into the conoid tubercle and trapezoid line of the clavicle. Bursae may occur at several sites near the top of the coracoid process, as found in about 10 to $30 \%$ of necropsy studies. ${ }^{12}$

Calcification in the coracoclavicular region may be due to calcification of intact or torn ligaments, ${ }^{34}$ but, in contrast to the case reported here, calcification of ligaments appears radiologically as streaks or lines in the shape of the ligaments. ${ }^{5}$ Shapeless cloudy calcification exceeding the territory of the ligaments, as in our patient, has been reported by McCurrich $^{6}$ in what seems to be the only reported case of calcifying coracoclavicular bursitis, proved by surgical removal of the calcified bursa.

In our patient pain seemed to be caused by moving the ligaments in relation to each other or by diminishing the distance between the two ligaments.
Elevating the arm is far more dependent on mobility of the scapula and on rotation of the clavicle than external and internal rotation. Therefore prominent, painful limitation of elevation, with normal glenohumeral abduction, seems to be the hallmark of coracoclavicular pathology.

\section{References}

1 Gruber W. Dic Oberschulterhakenschleimbeutel (Bursac mucosac supracoracoideac). Mém Acad Sci St Petersbourg (7th series) 1861: 3: 1-38.

2 Jaluvka V. Ueber dic Schleimbeutel und Faserknorpelige Berührungsflächen in der Umgebung des Ligamentum coracoclaviculare. Scr Med Fac Med Brun 1957; 30: 221-8.

3 Svab V. Posttraumatisch Ossification der Korakoklavikularbänder. ROEFO 1937: 55: 366-75

4 Soule A B. Ossification of the coracoclavicular ligament following dislocation of the acromioclavicular articulation. $A J$ $R$ 1946: 56: 6017-15.

5 Haas W H D de. Kingma M J. Drucker F. The coracoclavicular joint and related pathological conditions. Ann Rheum Dis 1965 24: 257-66.

$6 \mathrm{McCurrich} \mathrm{H} \mathrm{J}$. Calcification of the bursa of the coracoclavicular ligament. Br J Surg 1938; 26: 329-32. 